

DEN NORSKE LEGEFORENING

\title{
Når styrmannen svikter
}

LEDER

RENATE PETTERSEN

Renate Pettersen (f. 1951) er dr.med. og spesialist i indremedisin og geriatri. Hun er seksjonsoverlege ved Geriatrisk avdeling, Oslo universitetssykehus.

Forfatter har fylt ut ICMJE-skjemaet og oppgir ingen interessekonflikter.

Email: rrpettersen@yahoo.no

\section{Hjerneslag kan føre til svekkelse av komplekse kognitive funksjoner, ofte med dyptgripende konsekvenser for pasientenes autonomi. Er vi gode nok til å oppdage og håndtere slike problemer?}

Menneskehjernen har en unik tankekraft som gjør oss i stand til å planlegge, beslutte, initiere og gjennomføre handlinger på en hensiktsmessig måte, selv under skiftende ytre betingelser. Viktige elementer er blant annet motivasjon, konsentrasjon, utholdenhet, vekting av sanseinntrykk, arbeidshukommelse, abstraksjon, selvrefleksjon og kontinuerlig overvåking av egen atferd. Elementene samles under begrepet «eksekutive funksjoner» (kontroll- eller styringsfunksjoner). De er i stor grad knyttet til frontal/prefrontal cortex og dens subkortikale forbindelsesbaner til og fra alle andre hjerneområder. Dette er vårt eget Intranett, som overgår alle kunstige nettverk i effektivitet og fleksibilitet. Men et nettverk er ikke bedre enn sitt svakeste ledd, og med økende kompleksitet øker også sårbarheten hvis en skade skulle inntreffe.

Engstad og medarbeidere tar opp temaet eksekutiv svikt etter hjerneslag i dette nummer av Tidsskriftet (1). Hjerneslag er fremdeles den hyppigste årsak til uførhet hos voksne i den vestlige verden. I Norge er det ca. 15 ooo nye tilfeller per år, og omtrent 70 ooo mennesker lever med konsekvensene av sykdommen. Mortaliteten etter slag har gått ned de siste 20 år, mens insidensen har vært uendret, og sykdommen debuterer tidligere enn før (2). I l lys av en stadig mer langlivet befolkning og aldringen av de store etterkrigskullene må vi regne med økning i både prevalens og insidens av hjerneslag de neste 10-15 år (3).

Som det påpekes i artikkelen er det stort behov for mer kunnskap om eksekutiv svikt fordi slik svikt reduserer pasientens evne til å klare seg selv og fordi tilstanden er så kompleks at det er vanskelig å få et sannferdig bilde av den. Dilemmaet gjenspeiles i Helsedirektoratets nasjonale retningslinjer for behandling og rehabilitering ved hjerneslag, der eksekutiv svikt kun er representert med et kort avsnitt (4, s. 123). 
Gullstandarden for kartlegging av komplekse kognitive funksjoner er omfattende testing ved nevropsykolog, en ressurs som få slagenheter eller rehabiliteringsinstitusjoner i spesialisthelsetjenesten disponerer. Der den finnes, prioriteres de yngre og yrkesaktive, siden innsatsen hos dem antas å gi størst helseøkonomisk gevinst. De fleste slagpasienter er imidlertid eldre/gamle. Som regel er det leger, ergoterapeuter og sykepleiere i det tverrfaglige teamet som utfører kartleggingen. Jeg er enig i at god observasjon av pasienten ved skolert personell - kombinert med noen validerte tester - er best. Spørsmålet er om alle enheter i Norge rutinemessig bruker tester på eksekutiv svikt. Jeg tror det kan variere meget. Det finnes heller ingen konsensus i fagmiljøet om hvilke tester som bør brukes.

Noe av det vanskeligste i vår daglige virksomhet (og umulig ved uttalt afasi) er å skille mellom depresjon og eksekutiv svikt, siden apati, initiativløshet og nedsatt problemløsningsevne kan ses ved begge tilstander. En nyere litteraturgjennomgang indikerer at dårlig resultat på Verbal ordflyt-test og Stroop-test hos eldre uten språkvansker best avdekker ren eksekutiv svikt og kan forutsi dårlig respons på antidepressiver (5). Dog finnes det ikke spesifikke data om hjerneslagrammede. Pasienter med eksekutiv svikt etter slag kan være emosjonelt ustabile (gråter eller ler umotivert, på grunn av manglende kontroll over følelsene). Ifølge en Cochrane-analyse er det holdepunkter for at antidepressiv behandling raskt kan redusere både intensiteten og varigheten av symptomene, men studiene er små ( $\underline{6})$.

Å kjøre bil krever i høyeste grad intakte eksekutive evner. Trail Making Test B brukes ofte til kjørevurdering, men ikke alle kan alfabetet, selv ikke norskfødte. For å unngå problemet kan man anvende testen Useful Field of View (UFOV), som er validert for både slagpasienter og personer med demens (.7.). Den kan gjennomføres på kortere tid enn Nor-SDSA, som anbefales i de norske retningslinjene (4.).

Hva kan vi så gjøre for pasientene, bortsett fra generell aktivisering og tradisjonell slagrehabilitering? En fersk litteraturgjennomgang viser en mulig positiv effekt av trening i oppmerksomhet, arbeidshukommelse, selvkontroll og kompensatoriske strategier hos dem med følgetilstand etter slag ( $(\underline{8})$. Det ville være meget interessant å teste dette hos pasienter i postakutt fase, der hjernens plastisitet antas å være størst. Dessverre finnes det per i dag kun noen små pilotstudier. Her er det mye å gjøre.

Hjerneslag rammer som nevnt hovedsakelig de eldre. Andelen pasienter med cerebrovaskulær og/eller nevrodegenerativ komorbiditet øker med økende alder, og dermed risikoen for å utvikle eksekutive vansker. Mange bor alene og har lite sosialt nettverk. Ensomhet forsterker depressive tendenser og inaktivitet. Uansett hvor bra vi kan få pasientene - funksjonsnivået vil falle etter at rehabiliteringen er avsluttet. Da blir det særlig viktig med gode kommunale aktivitetstilbud, slik som eldresentre/dagsentre med tilknyttede fysio- og ergoterapeuter.

Norge er et lite land, men vi har gode samarbeidstradisjoner i Norden på mange områder. Jeg tror at de nordiske slag- og rehabiliteringsmiljøene kan utvikle en felles strategi for optimal kartlegging og håndtering av eksekutiv svikt, med hovedvekt på den postakutte fasen. Nye metoder for kognitiv rehabilitering trenger å utvikles, testes og siden deles med helsepersonell i og utenfor sykehus.

\section{LITTERATUR}

1. Engstad RT, Engstad TT, Davanger S et al. Eksekutiv svikt etter hjerneslag. Tidsskr Nor Legeforen 2013; 133: 524-7.

2. Kissela BM, Khoury JC, Alwell K et al. Age at stroke: temporal trends in stroke incidence in a large, biracial population. Neurology 2012; 79: 1781-7. [PubMed] [CrossRef]

3. Ellekjaer H, Selmer R. Hjerneslag - like mange rammes, men prognosen er bedre. Tidsskr Nor Lægeforen 2007; 127: 740-3. [PubMed] 
4. Nasjonal retningslinje for behandling og rehabilitering ved hjerneslag. IS-1688. Oslo: Helsedirektoratet, 2010.

5. Pimontel MA, Culang-Reinlieb ME, Morimoto SS et al. Executive dysfunction and treatment response in late-life depression. Int J Geriatr Psychiatry 2012; 27: 893-9. [PubMed] [CrossRef]

6. Hackett ML, Yang M, Anderson CS et al. Pharmaceutical interventions for emotionalism after stroke. Cochrane Database Syst Rev 2010; nr. 2: CDoo369o. [PubMed]

7. Marshall SC, Molnar F, Man-Son-Hing M et al. Predictors of driving ability following stroke: a systematic review. Top Stroke Rehabil 2007; 14: 98-114. [PubMed] [CrossRef]

8. Poulin V, Korner-Bitensky N, Dawson DR et al. Efficacy of executive function interventions after stroke: a systematic review. Top Stroke Rehabil 2012; 19: 158-71. [PubMed] [CrossRef]

Publisert: 5. mars 2013. Tidsskr Nor Legeforen. DOI: 10.4045/tidsskr.13.0125

(C) Tidsskrift for Den norske legeforening 2023. Lastet ned fra tidsskriftet.no 26. april 2023. 